\title{
Cultural Strengths to Persevere: Native American Women in Higher Education
}

Stephanie J. Waterman

Assistant Professor

Educational Leadership

University of Rochester

Lorinda S. Lindley

Education Consultant

Laramie, Wyoming

Beginning with an overview of historical perspectives of Native American women, this article includes some discussion of values and practices of contemporary Native American women, data pertaining to Native American women's participation in higher education, and an introduction offamilial cultural capital, community cultural wealth, Native resiliency, and nation-building capital (Lindley, 2009). The women in this article come from two very distinct tribal communities: the Northern Arapaho and Haudenosaunee (Iroquois). The women of both communities used culture, community, and family as foundations of their success in college. The concepts that make up these Native forms of capital are then connected to Native resiliency (Guillory, 2008), Native capital (Ward, 2005), and nation building.

Beatrice Medicine states bluntly,

It is counterproductive to dwell on the paucity of published works on $\mathrm{Na}$ tive American (American Indian) women. There is virtually no research in this area and no research agenda for the future (1988, p. 86)....Given the inadequate research base on American Indian (AI) women, one might predict the existence of an even smaller body of knowledge about their education. (Evans, 1994, p. 5)

Correspondence concerning this article should be addressed to Stephanie J. Waterman, swaterman@warner.rochester.edu. 
Unfortunately, at the beginning of 2012, Evans' (1994) assertion is still valid. Yet, Native American women engage in higher education at a higher rate than do Native American men, a reality that demands research to support this population. In 1976, 38,500 Native American/Alaska Native (NA/AN) men and 37,600 NA/AN women were enrolled in institutions of higher education (IHEs) (DeVoe, Darling-Churchill, \& Snyder, 2008). The number of females enrolled in IHEs grew to 108,000 in 2005, while only 68,400 males were enrolled (DeVoe et al., 2008). Women constituted the basis for the significant increase in enrollment levels for Native American students overall (Pavel et al., 1998). Particularly notable is the four-fold increase in Native American women earning masters, doctoral, and professional degrees (DeVoe et al., 2008).

The literature and the women in this article used several terms when referring to the Indigenous people of the Americas. The following terms are found in the literature: "American Indian," "Native American," and "Indigenous." Some Native people refer to their specific community as a "tribe," whereas others use the word "nation." Native participants referred to themselves by their individual nation (e.g., Northern Arapaho) and as Native, Native American, Indigenous, and Indian. For the entirety of this article, we refer to these individuals as "Native American" unless a specific concept uses a specific term, such as "Tribal Critical Race Theory."

This article combines two separate qualitative studies of women who completed college degrees: Northern Arapaho and Haudenosaunee (Iroquois). Cultural capital, in terms of familial cultural capital, community cultural wealth (Yosso, 2005, 2006) and nation-building capital (Lindley, 2009) were applied and further developed in the Northern Arapaho study. We discussed the cultural capital concepts in relation to our separate studies-from two very different contexts-wondering whether these concepts would apply to both. If that were so, it would strengthen the theories and add to our methodologies. Consequently, using axial coding (Charmaz, 2006) we coded our respective data through the lens of capital as defined in our Conceptual Framework. The purpose of this research was to investigate whether or not the cultural capital concepts applied to one group of Native women from Wyoming would apply to another group of Native women primarily from New York. We also felt that the greater number of participants would also serve to strengthen our findings. With this article, we add to the limited literature available on Native American women, especially at a time when Native women are attending and completing college in greater numbers than Native American men (Aud et al., 2011). An introduction of conceptual frameworks leads into the methodology of both studies and findings. As we seek to understand the experience of 
Native American women in IHEs, we must look to the past to inform present context.

\section{Historical Perspective of Native American Women}

Prior to contact with Europeans, Indigenous women and men had specific tasks that were defined by gender. All of the work was needed; while the duties were different, the work was equally valued and roles balanced (Antell, 2002; Mihesuah, 2003; Shenandoah, 1992). The intentional imposition of Europeans' ideology through the boarding school (Adams, 1995) eroded how traditional gender roles were valued and attempted to destroy Native family and social structure. Many Native American women suffered a loss of respect for what they do within their tribes. "Most observations of Indian women in traditional societies were written by Euro-American men, who judged them by the same standards that they judged women of their own societies" (Mihesuah, 2003, p. 45), if they saw women at all (Almeida, 1997). These judgments subjected Native American women to stereotypes depending upon the non-Native misunderstanding of tribal kinship systems, gender roles, spiritual and societal values. Although cultures have changed because of contact with non-Natives, Native women yet maintain many of their cultural roles in their societies (Mohawk, 2003; Shenandoah, 1992). For example, Haudenosaunee women continue to hold clan mother and faithkeeper roles that maintain ceremony and community life.

\section{Values and Practices of Contemporary Native American Women}

Allen (1992), a Laguna Pueblo scholar, described contemporary Native American women in this way: "Modern American Indian women, like their non-Indian sisters, are deeply engaged in the struggle to redefine themselves. In their struggle they must reconcile traditional tribal definitions of women with industrial and postindustrial non-Indian definitions" (p. 43). She added that, "An American Indian woman is defined by her tribal identity. In her eyes, her destiny is necessarily that of her people, and her sense of herself as a woman is first and foremost prescribed by tribe" (p. 43). This distinction is often not understood by the dominant culture, which emphasizes individualism.

Bataille and Sands (1984) explained that, although not all women from Native American tribes are alike, certain attributes are distinctive, noticeable, and significant to the identity of Native American women. These authors described how reticence "accounts for the frequent guardedness of narrators in 
focusing on their own emotions and private aspects of their lives" (1984, p. 18).

Native American women, according to Bataille and Sands (1984), are central to the spiritual health and balance of their tribes and "are characterized by responsibility for the steadfastness of tribal ideals and values" (p. 18). The resoluteness and faithfulness to traditions and values derive from "a concern for communal welfare, the subordination of the individual to the collective needs of the tribe" (Bataille \& Sands, 1984, p. 19). Bataille and Sands (1984) put forward a description of Native American women in this way:

Indian women are especially skilled in creating a community of womenwhat might today be called a support network-to share both responsibility and pleasure in the day-to-day tasks of life; and lest Indian women be seen as terribl[y] solemn .... .Humor is a central characteristic of Indian women, both traditionally and in contemporary life. (p. 19)

These characteristics of Native American women are "adaptable, enduring, and contemporary, and not simply . . . abstractions or ghosts of times past" (Bataille \& Sands, 1984, p. 19). The experiences of the women in this article bring to light the adaptability and ability of Native women to maintain traditions while using a formal education to strengthen their families and communities.

\section{Native American Women in College}

A library record search of Native American women in college was conducted including the terms "Indigenous," "American Indian," "postsecondary," and "college." The search resulted in several articles, but few were based on empirical research. For example, Medicine (1988) cited earlier calling for research on Native American women, was not necessarily specific to education; Edges (1993) compiled a list of resources on Native American women that is now dated; Evans (1994), apparently in response to Medicine (1998), provided a literature review, noting the importance of community colleges for Native women; and Pember (2008) featured three Native American women in leadership roles in an article for Diverse Issues in Higher Education. Although no articles about tribal colleges focused solely on women students, Ambler (1992) wrote about the prevalence of Native women in top leadership positions at tribal colleges. Outside the field of education, Brandt (2008) conducted a qualitative study with four Navajo women in science, finding the centrality of culture and family for her participants. 
As Evans lamented in 1994, few studies examined the college experience of Native American women. The studies that focused entirely on Native American women college students have similar findings. Skye, Christensen, and England's (1989) quantitative study of a Native dance model's effect on stress factors in Native American college women at one western institution found that the dance model reduced stress in one aspect of anxiety. White Shield (2009) conducted a qualitative study of eight Indigenous women regarding their educational experiences. Through a uniquely traditional research methodology using the Medicine Wheel, White Shield (2009) found four data "clusters," the first of which centered on spirituality as "an entire way of being" (p. 51) that provided strength for degree completion. The second cluster centered on how participants filtered their higher education experience through their culture (p. 53). White Shield (2009) discussed the traditional metaphors used in describing their experiences, such as a turtle-hard on the outside, soft on the inside, able to "take solace in their shells" (p. 55). In cluster three, White Shield (2009) identified that Native women found strength in "traditional cultural roles" (p. 56), an indication of the importance of culture and community. White Shield (2009) named the fourth cluster "Family Loyalty" (p. 58) because family was central for these women. "This cultural strength provided a resiliency factor when making difficult decisions relating to their academic experience" (White Shield, 2009, p. 58).

White Shield (2009) is not alone in finding resiliency in her data. Recent scholars describe Native American women in higher education as resilient, a term that is compatible with adaptable and enduring; examples of how women adapt a contemporary education within their own traditional framework are found in this literature. Shotton's (2008) qualitative study of eight highachieving Native American women found the participants, all with doctorates and representing a range of Native communities, responded to overt and covert racism with resiliency. Despite family financial difficulties, K-12 tracking, academic discouragement, and some "initial failure" (p. 102) in college, these women persevered and completed doctorates. Besides personal resilience and motivation, Shotton's participants named family, community, and supportive faculty in their support system. Reliance on traditions and spirituality as strengths to continue and complete their educations was also reported.

\section{Resiliency in Native American College Student Research}

Where preliminary research, often done by and through a non-Native perspective found Native American family, culture and language to be barriers to 
educational success (Meriam, 1928; Scott, 1986), recent research on Native American college students has found family, culture, and community to be vitally important to educational success (Brayboy, 2005a; Guillory, 2008; Fox, Lowe, \& McClellan, 2005; Waterman, 2007, 2012).

Resiliency is the ability to "overcome" stressful situations to achieve successful outcomes, maintain "competence," and recover from stress (Masten, Best \& Garmetzy, 1990, p. 425). Formal educational curriculum in the United States is founded on European and Christian models (Spring, 2005). The boarding school legacy is not merely historical to many tribal peoples. Pervasive well-earned attitudes of mistrust of education are very much alive today (Adams, 1988; Carney, 1999). Native Americans live in a country that historically had policies and practices aimed at their removal (Adams, 1995); they continue to experience racism on many levels (Chavers, 2009; Cook-Lynn, 2001; Perry, 2002). Yet, Native American students use their culture to be resilient in educational environments. Montgomery, Miville, Winterowd, Jeffries, and Baysden (2000) found that Native students integrate "traditional Indian ways and family values within all parts of [their] educational life" (p. 389) to be resilient and successful in college. Guillory's (2008) study of the concept of giving back for Native American college graduates found that the participants displayed resiliency during "critical junctures" in their lives (p. 176). Being Native American is unique in the United States and barriers are inherently in place because of that status; therefore, Guillory (2008) recommends that researchers use "culturally relevant language" (p. 175), writing,

Based on the ability of the participants in this study to overcome numerous adversities throughout their lives, the term Native Resilience is recommended as a beginning point in the development of culturally relevant scholarly language that may encapsulate the numerous complexities and contradictions that occur in the lives of Native people. (p. 175)

Thus, Native resilience, as a culturally relevant scholarly term, provides a bridge from the past to explain the complexities and liminality within the context of Native American students in IHEs.

\section{Conceptual Framework}

Given that spirituality, traditions, and culture are the basis for Native resiliency, it is important to discuss the conceptual framework of this article. Indigenous methodologies build the foundation for Tribal Critical Race Theory (Brayboy, 2005b). After conceptual approaches are discussed, forms of cultural 
capital (Yosso, 2005) follow; then, nation-building capital is introduced, and is connected to Native capital (Ward, 2005).

As Native American women, and as college students, Native American women college students have the unique knowledge of that experience (Collins, 2000; Waterman, 2007). Indigenous pedagogies take the additional step of indigenizing how voices are to be included and research approached (Mihesuah \& Wilson, 2004). Smith (1999) discussed how the scientific method has "othered" Indigenous people by making them exotic objects of study. Mother Earth became a resource of "untapped" markets (Smith, 1999, p. 98), distancing scientists who used science as a tool of colonization. One example of being colonized via research is by having one's DNA harvested. Researchers in Native communities must respect those communities and abide by their established norms (Smith, 1999). She also discussed crossing boundaries in the sense of exclusionary boundaries of the academy that devalue Indigenous scholarship.

Garroutte (2003) wrote that research must be done according to our "original instructions," (p. 115) meaning the original instructions from our Creator (or God) that guides behavior. Thus, Garroute (2003) defined Native scholarship in this way:

It is a scholarship in which questions are allowed to unfold within values, goals, categories of thought, and models of inquiry that are embedded in the philosophies of knowledge generated by Indian people, rather than in ones imposed upon them. (p. 144)

Grande $(2004,2008)$ reclaimed "red" (as in red power), disputing Whitestream feminist and critical theories as failures in addressing Native issues. She also called for a respect for tradition and worldview, but additionally acknowledged the complexity of Native peoples' existence, again, as a raced and gendered people. Grande (2004) wrote that borderlands, territories, reservations, and border towns, are "alter-native" spaces where Native people construct knowledge, theorize through stories, and continue traditions without outside interference (p. 169).

An approach that powerfully applies to alter-native spaces of Native people is Tribal Critical Race Theory (TribalCrit), which extends the premises of Critical Race Theory (CRT) to Native people and the liminal space $\mathrm{Na-}$ tive Americans uniquely occupy as political and racialized people within their homelands in the United States (Brayboy, 2005b). Brayboy (2005b) provides a framework to deconstruct the continuing impact of colonization and "expose the inconsistencies in structural systems and institutions ... [to] make the situation better for indigenous students" (Brayboy, 2005b, p. 441). A significant 
aspect of TribalCrit emphasizes that stories are not separate from theory; therefore, they make up theory and are real and legitimate sources of data and ways of being. Using TribalCrit in analyzing the experiences of her participants, the second author added Yosso's (2005) forms of cultural capital to describe the liminal spaces these women occupy, the customs and traditions that were central to their negotiation in a world dominated by non-Natives, and how their cultural center was their anchor.

\section{Sovereignty}

Central to a Native lens and TribalCrit is sovereignty. Tribes have government-to-government relationships with the United States. The following text is from President George W. Bush's Executive Order 13336:

The United States has a unique legal relationship with Indian tribes and a special relationship with Alaska Native entities as provided in the Constitution of the United States, treaties, and Federal statutes. This Administration is committed to continuing to work with these Federally recognized tribal governments on a government-to-government basis, and supports tribal sovereignty and self-determination. (Bush, 2004, p. 29295)

This unique status as sovereign nations and people is why many Native Americans refer to their individual tribe as "nation" and why Native Americans cannot be lumped in with other underrepresented groups.

For the Haudenosaunee, the first treaty with non-Natives was made with the Dutch in 1613, the Guswenta or Two Row Wampum. The Guswenta is an agreement of noninterference; the Haudenosaunee and Dutch agreed to be different, to respect one another's separate cultures and laws, and to not interfere in the internal affairs of the other (Barreiro, 1992; Tehanetorens, 1999). The Guswenta was enacted with the English and French when they made contact, and then when the United States was formed. The Haudenosaunee travel abroad on their own passports (Arden, 1987) and maintain their system of government that was in effect before contact with the colonists (Barreiro, 1992). This system is matrilineal, with nation, clan, and property passed down through the mother (Venables, 2004).

All members are responsible for sovereignty; "Sovereignty, then, began with the individual, and all people were recognized to be free, from the very youngest to the eldest" (Lyons, 1992, p. 33). In 1878, the Northern Arapaho were forced onto the Wind River reservation that they had to share with the Eastern Shoshone. They resisted termination, assimilation, and were success- 
ful in forcing the U.S. Government to pay monthly per capita payments to enrolled members (Fowler, 1982). From near extinction, Native American communities still exist, maintain their cultures, are revitalizing their languages and traditions while balancing today's influences - and they attend college. To maintain, to continue, and to thrive are responsibilities that today's Native Americans embrace. This is more complicated than individual success in economic terms, although economic growth is an important piece. Sovereignty, then, begins with the family.

\section{Community Cultural Wealth and Nation Building}

Community is at the core of the existence of Native nations. Survival of community is more important than any individual (Deloria \& Wildcat, 2001; Lomawaima \& McCarty, 2006). Yosso (2005) explained that community cultural wealth is "an array of knowledge, skills, abilities and contacts possessed by communities of color to survive and resist macro and microforms of oppression" (p. 77). From this perspective, cultural capital, that which constitutes community cultural wealth, encompasses all that is culturally learned, including values, beliefs, information, understandings, skills, and ways of engaging in particular practices (Rueda, Monzo, \& Arzubiaga, 2003). In other words, cultural capital is the what that is learned in community.

Not only do Native Americans rely on their cultural traditions as sources of strength, they are invested in the continuance of these traditions. These forms of cultural capital are interactive and dynamic facets of processes in which they are not mutually exclusive. Familial cultural capital is comprised of those cultural knowledges encouraged among intergenerational groups of relatives who have a sense of tribal and community history, memory, and cultural intuition (Brayboy, 1999, 2005a; Delgado Bernal, 1998, 2002; Waterman, 2004, 2007; Wells, 2008). This form of community cultural wealth encompasses a sense of obligation and responsibility to community well-being, which is based upon a much broader understanding and practice of kinship than that in the dominant culture of the United States (Anderson, 2001; Waterman, 2012; Wells, 2008). These forms of capital form the reserves of strength for Native resiliency (Guillory, 2008) to overcome barriers.

Native resiliency is an important concept when one considers the overt and covert barriers Native Americans experience as racialized and politicized people (Brayboy 2005b, Grande, 2004). School curricula are not Nativebased, and typically do not include Native epistemologies (Champagne, 2006). Courses are taught in English and as recently as February of 2012, a 
high school student was punished for speaking her Native language in school ("Student suspended," 2012). Many IHEs still use Native American mascots. Native Americans experience high rates of violence, more often inflicted by a non-Native (Perry, 2004) and Native American women, in particular, are at risk of dying from violence (Bachman, Zaykowski, Kallmyer, Poteyeva, \& Lanier, 2008). Western Native American communities are some of the poorest in the United States. The cultural capital based on families that support Native resiliency helps us understand what Ward (2005) terms Native capital:

The term Native capital represents the cultural resources of Native peoples, the particular ways in which American Indian community members internalize tribal values and orientations, engage in social relations and cultural practices, and develop skills and abilities needed to achieve success within their own communities. (p. 53)

Native capital, then, relies on the strength of families and community. To maintain a strong community, to continue as sovereign peoples, Native Americans engage in nation building. Nation building includes strengthening traditional languages, cultural traditions, and practice (traditional infrastructure), as well as economic endeavors (Brayboy, Fann, Castagno, \& Solyom, 2012). This does not necessarily entail participation in the democratic process of the United States, but rather focuses on building Native infrastructure to remain independent and self-determinant (Alfred, 1999; Grande, 2004). Obtaining a college degree to become a teacher to strengthen a tribe's language program is an example of nation building.

The conceptual framework used in this article builds upon the work of TribalCrit (Brayboy, 2005b). TribalCrit provides a roadmap for research and analysis of Native American experiences that are inherently complex. No other group of color in the United States experiences the liminal position of Native people who have blood percentage limits imposed by the federal government to "prove" $\mathrm{Na}$ tive identity (Garroutte, 2003, p. 31). The forms of community cultural wealth (Yosso, 2005), informed by CRT, challenge deficit models shifting the focus to the strengths of communities of color (p. 77). From this perspective, the many aspects of Native culture-family, traditions, ceremony, language_-are viewed as the basis of resiliency and capital that is distinctively Native.

\section{Methodology}

"If writers want to find out what Native women think, they should ask them" (Mihesuah, 2003, p. 4). Because we aim to understand how Native 
American women college graduates perceive their college educations, we have engaged in qualitative research, gathering the words and stories of the participants in these studies (Bogdan \& Biklen, 2007). Qualitative research is uniquely suited for the study of NA/AN college experiences because these college student populations are small in relation to the larger non-Native population, making it difficult to conduct valid statistical analysis (Tierney, 1992; Tinto, 1993). This is especially true when comparing Native American data to other groups.

Haudenosaunee college graduate interview data were gathered in 20022003 and 2005-2006, totaling 54 interview participants (37 of whom were women). The analysis for this article includes only the women's data. Twenty-six interviews with 16 Northern Arapaho women college graduates were gathered in 2005. In-depth interviews were conducted, transcribed, analytic memos written, and data analyzed using critical theories.

Through purposeful sampling (Bogdan \& Biklen, 2007) Haudenosaunee college graduates were solicited through an email posting on a Native American education listserv. The purpose of the larger study (that included men) was to learn how Haudenosaunee completed college degrees. Snowball sampling resulted in identifying many more participants throughout New York State and Canada. The Northern Arapaho study also involved purposeful sampling; college completers were sought, as this study emphasized how degrees were completed. The second author used snowball sampling from her contacts at the Wind River Reservation. Both studies obtained institutional IRB approval; the Northern Arapaho study also obtained tribal approval. At the time of the Haudenosaunee study, no means were available to obtain such permission. Most of the interviews were conducted in person (each lasting approximately an hour) at the participant's chosen location (home or office, for example). All interviews were open-ended focusing on the participant's K-20 educational experience. It is important in Native communities to ask "in a good way" (Lindley, 2009, p. 107); therefore, both authors brought gifts to the interviews. Culturally, it is important to give gifts; these gifts do not have to be extravagant. The first author offered homemade jam, paid for a meal or coffee; the second author offered blankets.

Strategies to ensure trustworthiness were the number of interviews (37 + 26), a consistent theoretical framework to guide the work, field notes, and collaboration with participants (Lincoln \& Guba, 1985). Native communities tend to be tight-knit; participants in both studies mentioned other participants in their interviews. In the Haudenosaunee study, administrators and faculty 
members were also interviewed who verified events shared among many of the interviews. In both studies, early interviews informed later interviews (Corbin $\&$ Strauss, 2008). The authors sought direction and guidance from other researchers in the field and with community members. This last point should not be overlooked. The first author is an insider to her community, adding another layer of responsibility to represent her community ethically while fulfilling her responsibility to the academic community (Hermes, 1999; Smith, 1999). The second author is an outsider to the community as a non-Native researcher. She worked and lived in the community for 9 years, building trust and family along the way, and maintains strong connections with many tribal members. Donna Deyhle (2009), also an outsider conducting research in a Native community was told by a Navajo elder, "To know about us, you have to grow old with us" (p. xxv). Trust is not easy to come by in Native communities; it must be earned and maintained. Where the second author depended on Native women (insiders) for confirmation, the first author depended on outsiders for an outsider's check (Brayboy \& Deyhle, 2000; Waterman, 2007). Both authors are aware of their position within their communities and higher education, a place that can be hostile toward Native people (Mihesuah \& Wilson, 2004; Smith, 2005; Trucks-Bordeaux, 2003).

The Haudenosaunee participants, who are sometimes referred to as a Woodland people, primarily live in New York State although several territories cross the imposed borders of the United States and Canada. The Haudenosaunee member nations are the Mohawk, Oneida, Onondaga, Cayuga, Seneca, and Tuscarora. No Bureau of Indian Education (BIE) schools exist in New York, and secondary education is provided through treaty obligations (Waterman \& Arnold, 2010). Although the Haudenosaunee territories are still rural, some are fairly close to cities. The Northern Arapaho are a Plains people living primarily in rural areas of Wyoming; the closest cities to their reservation are very small. The Northern Arapaho have two public school districts and one BIE school for secondary education.

Native communities are small and tight-knit; therefore, we only provide a demographic overview of the participants. In communities that are small enough to be able to identify all its college graduates, including participant major and age of degree completion would identify the participants. In addition, a particular community might have a single physician and, even when pseudonyms are used, her degree major would identify her. When quotes are provided, we use pseudonyms.

Thirteen of the 37 Haudenosaunee participants and all 16 of the Northern Arapaho women were mothers while attending college. Only one Northern 
Arapaho participant was in her early 20s while pursuing her college degree, whereas 11 of the women in the Haudenosaunee study were traditionally aged college students. In both studies, the ages ranged from the late 20 s to the mid30 s to one Haudenosaunee participant who completed her degree at the age of 48 and two Northern Arapaho women who were over 50 when they completed their degrees. Nine of the participants in the Haudenosaunee study needed more than 6.5 years to complete their degrees. In the Northern Arapaho data, one participant completed her degree within 5 years, and the rest ranged from 7-35 years from first matriculation to degree completion. All of the Northern Arapaho participants and 31 of the Haudenosaunee participants attended more than one institution in pursuit of a college degree.

The data are also presented as counterstories (Dixson \& Rousseau, 2005) and theory (Brayboy, 2005b). Counterstories are central to CRT and TribalCrit as they offer a different perspective from the "master scripting" (LadsonBillings, 1998) of common assumptions and stereotypes. An example of a master narrative is the deficit ideology commonly assigned to people of color. The stories of the women in this study are in vivid contrast to that ideology. In oral traditions, stories serve as more than ways to impart knowledge and history; theory is intimately linked to story. As Brayboy's (2005b) mother told him, "Baby, doesn't she [a former colleague] know that our stories are our theories?" (p. 426). Mohawk (1992) referred to Haudenosaunee law as a "thinking tradition" (p. 20) based on "responsible thinking" (p. 23). Stories can be interpreted through different contexts both affirming tradition while allowing for adaptability and growth. However, these discussions typically take place in "alter-native" spaces (Grande, 2004, p. 169), out of the view of non-Natives. Considering the few studies of Native American women college experiences, this study serves to add their distinctive stories to the larger conversation on college students.

\section{Discussion}

Familial cultural capital examples from the data will be presented first, as this concept is a component of community cultural wealth. Next we present examples of Native capital (Ward, 2005), Native resiliency, finally connecting all of these concepts to nation building.

Familial capital, as transmitted by groups of intergenerational relatives who use the forms of knowledge of their Native community and are guided by senses of tribal and community history, memory, and cultural intuition and knowledge (Brayboy, 1999; 2005a; Delgado Bernal, 1998, 2002; Waterman, 
2004, 2007; Wells, 2008) were found in the data. The focus of these women was on the collective, not the individual.

All of the Northern Arapaho participants referred to "strong Arapaho women." Just as Brayboy (1990) wrote of the importance of the motherdaughter relationship to the participants in her research, participants in this research spoke of the influence of their grandmothers, mothers, aunts, and sisters. As one participant explained, "I'm strong because of my mom. I'm strong because I believe in myself. . . . I'm strong because I know my, my beliefs as an Arapaho. ... Women are sacred because we carry on the cycle of life." This quote is just one example of how forms of knowledge transmitted intergenerationally (e.g., mother-to-daughter, grandmother-to-granddaughter) guide younger generations by providing senses of tribal and community history, memory, and cultural intuition and knowledge.

Haudenosaunee women role models stood out as triggers—as examples of college graduates inspiring young community members to attend collegeand mothers who went to college so their children could see it was possible. As an example, Candi's mother went to a 2-year college while holding a full-time job so Candi would finish high school. Candi quit high school because she was dealing with the death of her friend. Candi said her mom "now tells me she did it just so that $I$ would go back." Another Haudenosaunee participant and her mother graduated from college on the very same day; they walked through their graduation ceremony together. These are two examples of intergenerational educational value being passed from mother to daughter.

Women knew their culture and community would benefit from their obtaining an education, including their own families. Women considered children a reason to go to college or to finish a college degree to be able to provide for their children and be role models. A Haudenosaunee participant, Molly, is just one example of role model behavior when she said,

I had my son in December and things didn't work out with his father, so I ended up being a single mother which motivated me to go finish my last year at [private college] for my bachelor's ... I was thinking how that wouldn't look good if I'm encouraging him to do this [go to school] and do that; he's just going turn and around and say "Well, you quit."

Rhonda, a Northern Arapaho participant said, "I think at the beginning, when I went back, you know, I did it for my daughter. I wanted to quit drinking, I wanted to quit smoking, and I wanted to be a positive role model by going to school." 
The above examples of familial cultural capital also show that the women view education as strengthening their families and nations because, through a traditional lens and traditional roles, strengthening the family by being a role model and transmitting values from mother to daughter strengthens the nation. The women pursued higher education as a means of maintaining cultural integrity, but it is an indication that they viewed their education, as individual women, as greater than an individual's experience. As Ada, a Northern Arapaho participant expressed her experience:

Learning about myself, respecting myself as a Native person and going to a Ph.D. program, I realized that I have a responsibility to myself and to my children, to my family, to my community to adhere to those [Native] learning styles and be responsible for what I've learned. When I went back to the University this last time to get my Ph.D., it was difficult. When I was reading Indigenizing the Academy, I thought of being an activist, you know, making sure that people are hearing our voices loud and clear. I developed critical thinking and reached a turning point. I was no longer that oppressed Indian child, not just adhering to people and doing what they want any more like I was taught at a younger age. I know people are catalysts of change.

The women entered colonized environments (IHEs) to obtain their educations. IHEs typically view reservations and reservation life from a deficit model (Deyhle, 1995; Foley, 1996). Yet, the women used their communities and families, the backbone of a people's culture, as Native resilience, as a source of strength as they negotiated the IHE environment. For example, women from both groups relied on their cultural integrity to challenge professors and classmates who overtly stereotyped Native Americans. Lottie, a Northern Arapaho participant, shared:

I have a real strong sense of identity. I know who I am; I know where I come from. I took a class and the professor was using the word shaman consistently and I was just sick of it. I got really tired of him referring to our Indian doctors as shamans. And I thought, "You know what? I can't stand it anymore." I spoke up, [the] first time I spoke up in class. The first time I said anything in class I told him, "Indian people don't refer to our medicine men as shamans." I said, "That's an anthropological term. We don't call them that. And it sounds real hokey. We don't say that." And he got really upset with me. And he said, "Do you want to get up here and teach the class?" I said, "No, that's what you're getting paid to do." But 
that was the first time I spoke up in class and that was our conversation.... I didn't want to talk to him after that....

Their families and communities pressed upon the women responsibilities beyond academics. It was not possible for the women to walk away from these responsibilities because it would have meant walking away from their identity, from their nations.

To help the reader recognize these forms of capital examples of familial capital, community cultural wealth, Native capital that forms the basis of $\mathrm{Na}$ tive resiliency, and nation building follow. First, consider these words from Ruth, a Northern Arapaho:

The biggest push is my kids, I guess, as far as opening up, asking for support and not being shy ... getting to know a person for, not your skin color, but just who they are. And once I started doing that and realizing that and it, you know, I was able to finish here.

Ruth stated that she had support systems, "Indian people," people she could go to when she needed help. Her resiliency was bolstered by an assistantship where, she said, "they allowed me to do tribal research .... So that was the best - that was good. That best professor that I had...just understood tribal values, tribal government." In this course, she was able to use her tribal knowledge to have experience in research that valued her tribe. Of her coursework, she stated, "Okay, I learned this concept. What parts of it will work for me back at home, on my Reservation?"- an example of nation building.

Another example is a statement from Bonnie. She said: "Coming from a Haudenosaunee perspective that pushes you to do better, to make life better for everybody, not just yourself but for everybody and you want that." In this statement, Bonnie acknowledged her traditional Haudenosaunee worldview that drives a certain way of life that includes the community and that is desirable, not something to replace. As Bonnie and Ruth indicate, their personal education benefits their nations, illustrating the liminal space Native Americans occupy. Their educations help them become "catalysts of change" and agents of social change. Bonnie's statement is an example of how she filtered a formal education through her worldview, a worldview she values and maintains. Had Bonnie considered her culture a deficit or barrier to her educational achievement, she would not have framed the meaning of her education in this way. Again, Bonnie's story serves as an example of community cultural wealth as the basis of strength when negotiating her IHE experience, as an example of nation-building capital, and how intertwined these concepts are. 
The women in this article came from two distinct nations-Northern Arapaho women and Haudenosaunee women-yet displayed similar modes of adaptability and negotiation with the IHE environment relying on tradition, customs, and spirituality that were distinctively Northern Arapaho and distinctively Haudenosaunee. Familial cultural capital, as demonstrated by family and community support, is a part of community cultural wealth, the culture and traditions of Native communities - the glue- that binds a community. The women wanted to give back to their communities; they did not pursue education as a means to escape the reservation, but as a vehicle to strengthen their nations. The women valued their Native communities, cultures, and traditions as a distinct form of social capital, Native capital, which they relied on as they negotiated sometimes-hostile higher education environments. The point is that the women viewed their culture and communities as capital and used them as such, and through concepts of Native capital and resiliency to nation building. IHEs can also.

The concepts employed in this article based on TribalCrit (Brayboy, 2005b) and notions of Native capital and Native resilience will help higher education practitioners support Native American college students. These students' lived experiences, their counterstories, challenge deficit models. "Community cultural wealth creates space for the lived experience of Indigenous peoples, including the philosophies, beliefs, customs, traditions and visions for the future of tribes" (Lindley, 2009, p. 212). Next, we discuss limitations of this article.

\section{Limitations}

A limitation to this article is that while the themes and the nation-building form of cultural wealth were emergent from the Northern Arapaho data, the theoretical framework limits the analysis of the data simply because the authors used axial coding. There are other ways to interpret the data and researchers are encouraged to do so. For example, critical race theories such as TribalCrit center race and colonization in analysis. The authors encourage examination of the data with race as the unit of analysis. Another way to interpret the data is to examine the ways in which colonization might or might not play a part in the lives of these women.

Qualitative research is a labor-intensive endeavor. A qualitative researcher seeks rich data from fewer participants (Bogdan \& Biklen, 2007). Yet, because a vast amount of data can result, it is not possible to share all the important statements that were made; the qualitative researcher has to select carefully which words to use to represent the participants. This means the nuances of 
a culture, a person, or community, can be omitted because they are not pertinent to answering the research question. An additional limitation is that because the women in these studies were already college graduates, participant observation was not possible.

The first author is a member of the community she researches and must acknowledge that answers to questions may have been influenced by a participant not wanting to brag about herself or by the potential sharing of family secrets. Although we share the same basic culture, there are differences and, like any group of people, differences of opinion.

The second author is non-Native and although known in the community where she collected data, she was still an educated White woman doing research on Native Americans. Educated White people have exploited Native communities as research sites that have had no benefit to the community whatsoever (Smith, 1999). The second author's positionality as such challenged rapport with participants. She shared,

This perception created an enormous challenge to rapport: some of the participants clearly did not trust me enough to discuss sensitive subjects such as race or gender. This dilemma was negatively recursive. When I became aware of their hesitation and tried to put them at ease, my efforts seemed to be perceived as pushy, and they became even more reluctant to talk openly. (Lindley, 2009, p. 135)

The second author also struggled with Native humor. As researchers, we cannot eliminate all biases or limitations, but as good researchers, we need to acknowledge them.

\section{Recommendations}

This article was grounded on TribalCrit (Brayboy, 2005b) and a conceptual framework that did not "damage" (Tuck, 2009) the population under study. This allowed the researchers to see modes of capital in communities and cultures that were previously framed as deficit (Deyhle \& Swisher, 1997). These findings underscore the importance of using Native theory so that we more accurately interpret data as experienced by our Native participants. TribalCrit, in particular, provides a roadmap to center Native experiences for those non-Natives who wish to research Native issues. The authors recommend $\mathrm{Na}$ tive methodologies and theories when conducting research with Natives; otherwise, misunderstandings and stereotypes will continue. 
The women in this article relied on their communities and traditions in their navigation of higher education. How can IHEs support college students who seek a mainstream education and are deeply committed to their Native culture and family? Specifically, we call for more research on the navigational skills in which Native college women engage to complete college successfully. We also call for research on how Native college women are perceived by IHEs. Native themed residence halls, Native faculty, and Native cultural centers on our college campuses are important sites to explore. Cultural competency professional development on the part of IHE faculty and staff would benefit the IHE and the Native population on and off the campus, as well as other underrepresented groups.

Thirteen of the 37 Haudenosaunee women and all of the Northern Arapaho women in this article were mothers; therefore, it is clear that adequate childcare and housing must be made available and affordable. To pursue a higher education, some women in the Northern Arapaho data and two Haudensosaunee women had to leave their children in the care of grandparents who were miles away. Support for this population has to include childcare and, perhaps, a new look at campus housing, one that not only welcomes children, but also includes family members who might be able to help with childcare. If an institution is not able to support families on campus, what other ways could the institution support mothers? One way is to support the mother's travel to and from family.

The women in this article wanted to give back to their communities. Their personal educations were in the context of their larger community, as indicated by their wish to work for their communities after degree attainment and to serve as role models. If this population desires an education that allows them to give back, how can IHEs gear internship and classroom experiences toward that end? It is imperative that IHEs forge respectful connections with Native communities to help Native students maintain their community membership and responsibilities-something most Native students desire. Partnerships with tribes will not only help retain these students, but enrich the IHE as well.

IHE systems differ from Native community systems and some students might need help understanding how to navigate between the two. That does not mean that every Native American woman needs explicit direction in how to do so; however, IHE personnel use higher education specific acronyms and are enmeshed in a bureaucratic system that can differ from institution to institution and even from one department to another, resulting in need for translation and assistance at times. 
Considering the lack of research in this area, we recommend more studies of Native American women in IHEs period. More qualitative research is needed with Native American women in college-those who have completed college and those who have left-to help us understand this population. Quantitative data like NCES and IPEDS collect demographic data such as gender and ethnicity, so secondary data sources could be explored. What can we learn from these quantitative data? Moreover, Native women are emerging as leaders in Native higher education. It is interesting to note that many tribal colleges and universities (TCUs) are headed by women (12 out of 34 regular members; see American Indian Higher Education Consortium, 2013). How did these women work their way to the top of those institutions and what can we learn from them and from their leadership styles? What roles are Native women playing higher education leadership?

We also recommend research on the general Native American college student population, as that is lacking as well. It would also be prudent to investigate the shortfall in Native American male participation. Is there a critical point where males are pushed out or leave the system? It is critical that we understand what is happening with Native American males in higher education.

\section{Conclusion}

Through a Native lens, the experiences of the women in this article-community, family, tradition, cultural integrity - were expressed as the anchors that provided the sustenance to be Native American women in the United States. This article began with an introduction to Native American women. Theoretical constructs were discussed, and methodology and findings of research studies followed. Tribal Critical Race Theory (Brayboy, 2005b) provided the framework for the article. The second author's concept of nation building capital was explained, and examples were provided. Those ideas were then connected to Guillory's (2008) concept of Native resilience and Ward's (2005) concept of Native capital. We urged researchers and practitioners to use theory to expose cultural wealth and other strengths of communities of color.

Research on the Native American female experience in professionalization, as well as other research on natives, needs to be placed in a framework that takes into account the varied contexts, roles, and commitments that comprise the experiences of their lives. (Medicine, 1988, p. 92) 
We employed critical theories and concepts of cultural wealth as the framework to understand the experiences of Native women who have attained college degrees. This article provides the valuable perspective of 53 Native American women who successfully navigated the higher education system contributing a valuable and missing perspective to the scarce literature on Native Americans.

\section{References}

Adams, D. W. (1988). Fundamental considerations: The deep meaning of Native American schooling, 1880-1900. Harvard Educational Review, 58(1), 1-28.

Adams, D. W. (1995). Education for extinction: American Indians and the boarding school experience: 1875-1928. Lawrence, KS: University of Press of Kansas.

American Indian Higher Education Consortium. (2013, June). TCU Roster. Retrieved from http://www.aihec.org/colleges/TCUroster.cfm

Alfred, T. (1999). Peace, power, righteousness. Don Mills, ON: Oxford University Press.

Allen, P. G. (1992). The Sacred hoop: Recovering the feminine in American Indian traditions: With a new preface. Boston, MA: Beacon Press.

Almeida, D. (1997). The hidden half: A history of Native American women's education. Harvard Educational Review, 67(4), 757-771.

Ambler, M. (1992). Women leaders in Indian education: More women are running tribal colleges. What does this mean for the future of Native American societies? Tribal College, III(4), 10-10. Retrieved from http:// search.proquest.com/docview/231753679?

Anderson, J. (2001). The four hills of life: Northern Arapaho knowledge and life movement. Lincoln, NB: University of Nebraska Press.

Antell, J. (1997). American Indian women: A collection of materials related to American Indian women. Laramie, WY: University of Wyoming.

Arden, H. (1987, September). The fire that never dies. National Geographic, 172(3), 370-403.

Aud, S., Hussar, W., Kena, G., Bianco, K., Frohlich, L., Kemp, J., \& Tahan, K. (2011). The Condition of Education 2011 (NCES 2011-033). Washington, DC: U.S. Department of Education, National Center for Education Statistics.

Bachman, R., Zaykowski, H., Kallmyer, R., Poteyeva, M., \& Lanier, C. (2008). Violence against American Indian and Alaska Native women and the criminal justice response: What is known. Unpublished report. U.S. Department of 
Justice No. 223691. Retrieved from http://www.nij.gov/nij/topics/tribaljustice/vaw-research/welcome.htm

Barreiro, J. (Ed.). (1992). Indian roots of American democracy. Ithaca, NY: Akwe:kon Press.

Bataille, G., \& Sands, K. (1984). American Indian women: Telling their lives. Lincoln, NB: University of Nebraska Press.

Bogdan, R. C., \& Biklen, S. K. (2007). Qualitative research for education: An introduction to theories and methods (5th ed.). Boston, MA: Pearson.

Brandt, C. B. (2008). Scientific discourse in the academy: A case of an American Indian undergraduate. Science Education, 92(5), 825-847.

Brayboy, B. M. J. (2005a). Transformational resistance and social justice: American Indians in Ivy League universities. Anthropology and Education Quarterly, 36(3), 193-211.

Brayboy, B. M. J. (2005b). Toward a tribal critical race theory in education. The Urban Review, 37(5), 425-446.

Brayboy, B. M. (1999). Climbing the ivy: Examining the experiences of academically successful Native American Indian undergraduates at two Ivy League universities. (Doctoral dissertation). Retrieved from ProQuest Digital Dissertation database. (AAT 9926100)

Brayboy , B. M. J, Fann, A. J., Castagno, A. E., \& Solyom, J. A. (2012). Postsecondary education for American Indian and Alaska Natives: Higher education for nation building and self-determination. ASHE Higher Education Report, 37(5), 1-154. San Francisco, CA: Jossey-Bass. doi:10.1002/ aehe.3705

Brayboy, B. M., \& Deyhle, D. (2000). Insider-outsider: Researchers in American Indian communities. Theory into Practice, 39(3), 163-169.

Brayboy, M. (1990). Voices of Indianness: The lived world of Native American women. Unpublished doctoral dissertation. Retrieved from ProQuest Digital Dissertation database. (ATT9121483)

Bush, G. W. (2004, May 5). Executive Order 13336: American Indian Alaska Native Education. Federal Register, 69(87). Retrieved from http://edocket. access.gpo.gov/2004/pdf/04-10377.pdf

Carney, C. M. (1999). Native American higher education in the United States. New Brunswick, NJ: Transaction.

Champagne, D. (2006). Education, culture, and nation building: Development of the tribal learning community and educational exchange. In I. Abu-Saad \& D. Champagne (Eds.), Indigenous Education and Empowerment (pp. 147-168). Lanham, MD: AltaMira Press. 
Charmaz, K. (2006). Constructing grounded theory: A practical guide through qualitative analysis. Thousand Oaks, CA: Sage.

Chavers, D. (2009). Racism in Indian country. New York, NY: Peter Lang.

Collins, P. H. (1995). The social construction of Black feminist thought. In C. Turner, M. Garcia, A. Nora \& L. I. Rendón (Eds.), Racial and Ethnic Diversity in Higher Education (pp. 115-133). Needham, MA: Simon \& Schuster.

Cook-Lynn, E. (2001). Anti-Indianism in modern America: A voice from Tatekeya's Earth. Urbana, IL: University of Illinois Press.

Corbin, J. \& Strauss, A. (2008). Basics of Qualitative Research (3rd ed.). Thousand Oaks, CA: Sage.

Delgado Bernal, D. (1998). Using a Chicana feminist epistemology in educational research, Harvard Educational Review, 68, 555-582.

Delgado Bernal, D. (2002). Critical race theory, Latino critical theory, and critical race-gendered epistemologies: Recognizing students of color as holders and creators of knowledge, Qualitative Inquiry, 8(1), 105-126.

Deloria, V., Jr., \& Wildcat, D. R. (2001). Power and place: Indian education in America. Golden, CO: Fulcrum Resources.

DeVoe, J. F., Darling-Churchill, K. E., \& Snyder, T. D. (2008). Status and trends in the education of American Indians and Alaska Natives: 2008 National Center for Education Statistics, Institution of Education Sciences. Washington, DC: U.S. Department of Education.

Deyhle, D. (2009). Reflections in place: Connected lives of Navajo women. Tucson, AZ: The University of Arizona Press.

Deyhle, D. (1995). Navajo youth and Anglo racism: Cultural integrity and resistance. Harvard Educational Review, 65(3), 403-444.

Deyhle, D., \& Swisher, K. (1997). Research in American Indian and Alaska Native education: From assimilation to self-determination. In M. W. Apple \& D. Cooper (Eds.), Review of research in education (Vol. 22, pp. 113-194). Washington, DC: American Educational Research Association.

Dixson, A. D., \& Rousseau, C. K. (2005). And we are still not saved: Critical race theory in education ten years later. In A. D. Dixson \& C. K. Rousseau (Eds.) Critical race theory in education: All God's children got a song. New York, NY: Routledge.

Edges, M. L. (1993). Native American women in higher education: A pathfinder. Resource prepared for the Third Annual American Indian Education Conference, Austin, TX.

Evans, B. C. (1994). Education of American Indian women: A call for action. Community College Review, 22(2), 5-15. 
Foley, D. E. (1996). The silent Indian as a cultural production. In B. A. Levinson, D. E. Foley \& D. C. Holland (Eds.), The cultural production of the educated person: Critical ethnographies of schooling and local practice (pp. 79-91). Albany, NY: State University of New York Press.

Fowler, L. (1982). Arapahoe politics, 1851-1978: Symbols in crises of authority. Lincoln, NB: University of Nebraska Press.

Fox, M. J. T., Lowe, S. C., \& McClellan, G. S. (Eds.). (2005). New directions for student services: Serving Native American students. San Francisco, CA: Jossey-Bass.

Garroutte, E. M. (2003). Real Indians: Identity and the survival of Native America. Berkeley, CA: University of California Press.

Grande, S. (2008). Red pedagogy: The un-methodology. In N. K. Denzin, Y. S. Lincoln \& L. T. Smith (Eds.), Handbook of critical and indigenous methodologies (pp. 233-254). Los Angeles, CA: Sage.

Grande, S. (2004). Red pedagogy: Native American social and political thought. Lanham, MD: Rowman \& Littlefield.

Guillory, J. (2008). Diverse pathways of "giving back" to tribal community: Perceptions of Native American college graduates. (Doctoral dissertation). Retrieved from ProQuest Digital Dissertation database. (AAT 3370393)

Hermes, M. (1999). Research methods as a situated response: Toward a First Nations' methodology. In L. Parker, D. Deyhle \& S. A. Villenas (Eds.), Race is-race isn't: Critical race theory and qualitative studies in education (pp. 83-100). Boulder, CO: Westview Press.

Student suspended for speaking Native American language. (2012, February 7). Retrieved from Indian Country Today at http://indiancountrytodaymedianetwork.com/2012/02/07/student-suspended-for-speaking-nativeamerican-language- 96340

Ladson-Billings, G. (1998). Just what is critical race theory and what's it doing in a nice field like education? Qualitative Studies in Education, 11(1), 7-24.

Lincoln, Y. S., \& Guba, E. G. (1984). Naturalistic inquiry. Beverly Hills, CA: Sage.

Lindley, L. (2009). A Tribal Critical Race Theory analysis of academic attainment: A qualitative study of sixteen Northern Arapaho women who earned degrees at the University of Wyoming. (Doctoral dissertation). Retrieved from ProQuest Digital Dissertation database. (AAT 3387282)

Lomawaima, K., \& McCarty, T. (2006). To remain an Indian: Lessons in democracy from a century of Native American education. New York, NY: Teachers College Press. 
Lyons, O., Mohawk, J., DeLoria, V., Hauptman, L. M., Berman, H., Grinde, D., \& Venables, R. W. (1992). Exiled in the land of the free: Democracy, Indian nations, and the U.S. Constitution. Santa Fe, NM: Clear Light.

Masten, A. S., Best, K. M., \& Garmezy, N. (1990). Resilience and development: Contributions from the study of children who overcome adversity. Development and Psychopathology, 2, 425-444.

Medicine, B. (1988). Native American (Indian) women: A call for research. Anthropology \& Education Quarterly, 19(2), 86-92.

Meriam, L. (1928). The problem of Indian administration: Report of a survey made at the request of Honorable Hubert Work, secretary of the interior, and submitted to him, February 21, 1928. Washington, DC: The Brookings Institution.

Mihesuah, D. A. (2003). Indigenous American women: Decolonization, empowerment, activism. Lincoln, NB: University of Nebraska Press.

Mihesuah, D. A., \& Wilson, A. C. (Eds.). (2004). Indigenizing the academy: Transforming scholarship and empowering communities. Lincoln, NB: University of Nebraska Press.

Mohawk, J. C. (1992). The Indian way is a thinking tradition. In J. Barreiro (Ed.), Indian roots of American democracy (pp. 20-29). Ithaca, NY: Akwe:kon Press.

Mohawk, J. C. (2003). The power of Seneca women and the legacy of Handsome Lake. In R. A. Grounds, G. E. Tinker \& D. E. Wilkins (Eds.), Native voices: American Indian identity and resistance (pp. 20-34). Lawrence, KS: University Press of Kansas.

Montgomery, D., Miville, M. L., Winterowd, C., Jeffries, B., \& Baysden, M. F. (2000). American Indian college students: An exploration into resiliency factors revealed through personal stories. Cultural Diversity and Ethnic Minority Psychology, 6(4), 387-398. doi:10.1037//1099-9809.6.4.387

Pavel, D. M., Skinner, R., Cahalan, M., Tippeconnic, J., \& Stein, W. (1998). American Indians and Alaskan Natives in postsecondary education. Washington, DC: U.S. Department of Education.

Pember, M. A. (2008). Changing roles in Indian country: Women are emerging from positions of authority in traditional tribal culture to more public roles. Diverse Issues in Higher Education, 25(21), 11-12.

Perry, S. W. (2004, December). American Indians and crime: A BJS statistical profile, 1992-2002. (Publication No. NCJ 203097). Washington, DC: U. S. Department of Justice, Office of Justice Programs, Bureau of Justice Statistics. 
Perry, B. (2002). American Indian victims of campus ethnoviolence. Journal of American Indian Education, 41(1), 35-55.

Rueda, R., Monzo, L., \& Arzubiaga, A. (2003). Academic instrumental knowledge: Deconstructing cultural capital theory for strategic intervention approaches. Current Issues in Education, 6(14). Retrieved from http:// cie.ed.asu.edu/volume6/number14/

Scott, W. J. (1986). Attachment to Indian culture and the "difficult situation": A study of American Indian college students. Youth \& Society, 17(4), 381-395.

Shenandoah, A. (1992). Everything has to be in balance. In J. Barrreio (Ed.) Indian roots of American democracy (pp. 36-42). Ithaca, NY: Akwe:kon Press.

Shotton, H. J. (2008). Pathway to the Ph.D.: Experiences of high achieving American Indian females. Retrieved from ProQuest Digital Dissertation database. (AAT 3304231)

Skye, F. D., Christensen, O. J., \& England, J. T. (1989). A study of the effects of a culturally based dance education model on identified stress factors in American Indian college women. Journal of American Indian Education, 29(1), 26-31.

Smith, L. T. (2005). On tricky ground: Researching the Native in the age of uncertainty. In N. K. Denzin \& Y. S. Lincoln (Eds.) The Sage Handbook of Qualitative Research (3rd ed.). Thousand Oaks, CA: Sage.

Smith, L. T. (1999). Decolonizing methodologies: Research and indigenous peoples. New York,

Spring, J. (2005). The American School, 1624-2004 (6th ed.). New York: McGraw-Hill. NY: Zed Books.

Tehanetorens, F. R. (1999). Wampum belts of the Iroquois. Summertown, TN: Book.

Tierney, W. G. (1992). Official encouragement, institutional discouragement: Minorities in academe-The Native American experience. Norwood, NJ: Ablex.

Tinto, V. (1993). Leaving college: Rethinking the causes and cures of attrition (2nd ed.). Chicago, IL: University of Chicago Press.

Trucks-Bordeaux, T. (2003). Academic massacres: The story of two American Indian women and their struggle to survive academia. The American Indian Quarterly, 27(1\&2), 416-419. doi:10.1353/aiq.2004.0057

Tuck, E. (2009). Suspending damage: A letter to communities. Harvard Educational Review, 79(3), 409-429. 
Venables, R. W. (2004). American Indian history: Five centuries of conflict \& coexistence (Vol. II: Confrontation, adaptation \& assimilation, 1783-present). Sante Fe, NM: Clear Light.

Ward, C. J. (2005). Native Americans in the school system: Family, community and academic achievement. Lanham, MD: AltaMira Press.

Waterman, S. J. (2012). Home-going as a strategy for success among Haudenosaunee college and university students. Journal of Student Affairs Research and Practice, 49(2), 193-209. doi:10.1515/jsarp-2012-6378

Waterman, S. J. \& Arnold, P. P. (2010). The Haudenosaunee flag raising: Cultural symbols and intercultural contact. Journal of American Indian Education, 49(1\&2), 125-144.

Waterman, S. J. (2007). A complex path to Haudenosaunee degree completion. Journal of American Indian Education, 46(1), 20-40.

Waterman, S. J. (2004). The Haudenosaunee college experience: A complex path to degree completion. (Doctoral dissertation). Retrieved from ProQuest Digital Dissertation database. (AAT 3132719)

Wells, V. (2008). Let their voices be heard: Understanding the perspectives of Northern Arapaho preschool parents' attitudes and beliefs regarding language revitalization and cultural maintenance. (Doctoral dissertation). Retrieved from ProQuest Digital Dissertation database. (AAT 3320740)

White Shield, R. (2009). Identifying and understanding Indigenous cultural and spiritual strengths in the higher education experiences of Indigenous women. Wicazo Sa Review, 24(1), 47-63.

Yosso, T. J. (2006). Whose culture has capital? A critical race theory discussion of community cultural wealth. In A. D. Dixson and C. K. Rousseau (Eds.) Critical race theory in education: All God's children got a song. New York, NY: Routledge.

Yosso, T. J. (2005). Whose culture has capital? A Critical Race Theory discussion of community cultural wealth. Race Ethnicity and Education, 8(1), 69-91. 